\title{
A Case of Tonsillectomy and Adenoidectomy in Child With Down Syndrome With Obstructive Sleep Apnea
}

\author{
Chang Bin Yun ${ }^{1}$, Ki Jong Hyun ${ }^{1}$, Hyunzu Kim², and Young Hyo Kim ${ }^{1}$ (iD \\ Departments of ${ }^{1}$ Otorhinolaryngology-Head and Neck Surgery and ${ }^{2}$ Anesthesiology and Pain Medicine, Inha University Hospital, \\ Incheon, Korea
}

폐쇄성 수면무호흡이 있는 다운증후군 소아에서의 편도 및 아데노이드 절제술 1예

윤창빈 $^{1} \cdot$ 현기종 $^{1} \cdot$ 김현주 $^{2} \cdot$ 김영효 $^{1}$

인하대학교병원 ${ }^{1}$ 이비인후과, ${ }^{2}$ 마취통증의학과

Received November 2, 2021

Revised December 21, 2021

Accepted December 21, 2021

Address for correspondence

Young Hyo Kim, MD, PhD

Department of Otorhinolaryngology-

Head and Neck Surgery,

Inha University Hospital,

27 Inhang-ro, Jung-gu,

Incheon 22332, Korea

Tel $+82-32-890-2437$

Fax $+82-32-890-3580$

E-mail inhaorl@inha.ac.kr
Children with obstructive sleep apnea (OSA) show symptoms such as snoring, sleep apnea, and oral breathing. The diagnosis of the disease can be made through polysomnography and as the most common causes are tonsillar and adenoid hypertrophy, tonsillectomy and adenoidectomy ( $\mathrm{T}$ et $\mathrm{A}$ ) are considered as initial treatment. OSA is an increasingly recognized problem in children with Down syndrome, who are more prone to facial hypoplasia, hypoplasia of the mandible, and have a large tongue. In OSA Down syndrome patients, $\mathrm{T}$ et $\mathrm{A}$ can be performed if tonsillar hypertrophy is present. However, because these patients have underlying diseases (atlatoaxial unstability, airway problem, heart problem, endocrine problem), general anesthesia may be difficult and cervical extension may be limited during the operation. We describe a case of 10-year-old child with Down syndrome and OSA, who underwent $\mathrm{T}$ et A under general anesthesia through multidisciplinary care.

Korean J Otorhinolaryngol-Head Neck Surg 2022;65(8):457-60

Keywords Down syndrome; Obstructive sleep apnea; Tonsillectomy.

\section{서 론}

소아에서 폐쇄성 수면무호흡증은 코골이, 수면 중 무호흡, 구강 호흡 등의 증상을 유발할 수 있으며, 이로 인해 주간 졸 림증이나 학습장애, 행동장애, 성장장애 등을 유발할 수 있 고 야뇨증이나 주의력결핍장애와도 관련이 있는 것으로 알려 져 있다. ${ }^{1}$ 이를 유발하는 가장 흔한 원인은 편도 및 아데노이 드의 비대이기 때문에, 소아 폐쇄성 수면무호흡증 환자에서의 초기 치료로 가장 먼저 고려하는 것은 편도 및 아데노이드 절 제술이다. ${ }^{2)}$ 실제로 수술 후 코골이, 수면무호흡, 구강호흡과 같은 주요 증상뿐 아니라 주의력결핍과 과잉행동장애 등에

This is an Open Access article distributed under the terms of the Creative Commons Attribution Non-Commercial License (https://creativecommons.org/licenses/by-nc/4.0) which permits unrestricted non-commercial use, distribution, and reproduction in any medium, provided the original work is properly cited.
서도 호전을 보였다는 보고들이 있다. ${ }^{3)}$

다운증후군은 염색체 이상이 원인이 되는 질환으로, 21 번 염색체가 삼배성(trisomy)을 나타낸다. 이 증후군이 있는 환 아는 비만과 하악 저형성, 설비대가 있을 가능성이 높기 때문 에 이로 인한 코골이 및 수면장애가 더 흔히 나타난다. ${ }^{4)}$ 또한, 선천성 심장 기형을 비롯하여 여러 가지 동반장애를 가지고 있어 전신마취 및 진정 시에 위험요소를 많이 가지고 있는데, 특히 환축추(atlantoaxial)의 불안정이 있고, 비만, 하악 저형 성, 설비대, 위식도 역류증으로 기도확보에 어려움을 가져올 수 있다. 이외에도 당뇨, 갑상선 질환, 정신과적 질환 등의 동 반 질환은 내과적 응급을 동반할 수 있다. ${ }^{5}$

저자들은 폐쇄성 수면무호흡증과 함께 다운증후군 관련 합병증(atlantoaxial subluxation)이 있는 환아를 소아청소년 과 및 마취통증의학과와 협진을 통해 합병증 없이 성공적으 
로 편도절제술을 시행하였으며, 그 결과 코골이 및 수면무호 흡 증상을 호전시켜 이에 대해 문헌 고찰과 함께 보고하는 바이다.

\section{증 례}

환아는 10 세 여아로, 다운증후군으로 진단받고 소아청소 년과에서 경과 관찰하는 중에 수년째 지속되는 코골이 증상 으로 폐쇄성 수면무호흡증에 대한 평가를 위해 이비인후과 에 의뢰되었다.

환아 과거력에서 심방 중격 결손증(atrial septal defect)이 있으며, 갑상선 기능 저하증(hypothyroidism)이 있었다. 또한 8년 전 환축추 아탈구(atlantoaxial subluxation)로 제1-2 경 추 고정술(C1-C2 fixation)을 받은 수술력이 있었다(Fig. 1).

환아 및 보호자 문진상 코골이와 동반하여 구강호흡이 있 고, 수면무호흡 증상이 있었다. 그 외 주간 졸림, 과잉행동, 행 동장애 등은 없었고, 코막힘과 같은 비강 증상도 보이지 않았 다. 진료 시에는 구강 및 비강 진찰 등에 대한 협조가 잘되어 무리없이 평가가 가능했는데, 신체 진찰상 키 $116.2 \mathrm{~cm}$, 체중 $28.5 \mathrm{~kg}$ 으로(BMI 21.11) 과체중이었으며, 구강 진찰상 tonsil grade IV, palate grade II, Friedman stage I 소견이 있었다. 또한 다운증후군 환아에서 볼 수 있는 하악 저형성 및 큰 혀 를 동반하고 있었다.

이 환아의 경우 편도절제술을 통해 수면무호흡을 호전시 킬 수 있는 상황이었으나, 다운증후군에 따른 환축추아탈구, 심방 중격 결손증, 갑상선 기능 저하증의 기저질환으로 인해 수술 시 합병증의 위험이 높아 마취통증의학과 및 소아청소 년과와 다학제 진료(multidisciplinary care)를 진행했다. 다 학제 진료 결과, 환아는 폐동맥 고혈압이 없기 때문에 전신마 취 수술에 대한 위험도는 낮으며, 수술 후 수면무호흡이 호전

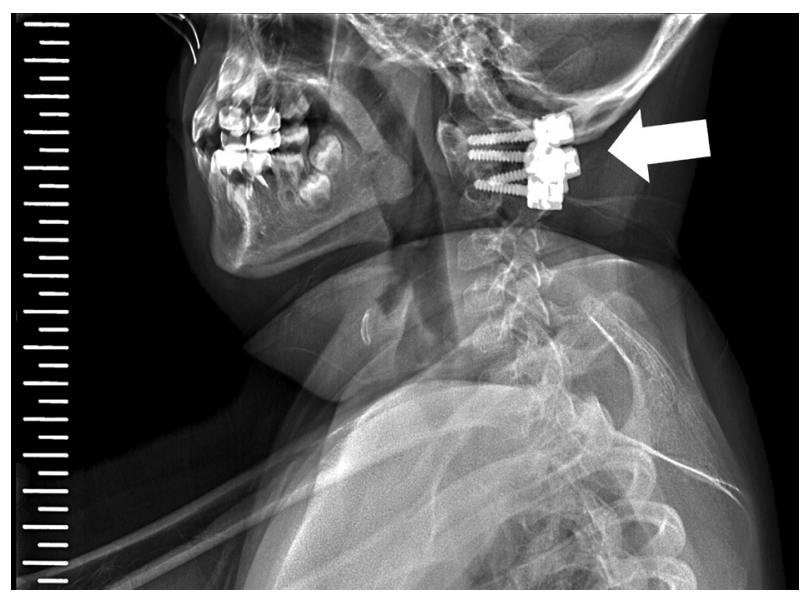

Fig. 1. Radiograph of the patient's c-spine, lateral view, showing C1-C2 fixation (arrow).
되면 심장 및 뇌혈관 질환의 이환율을 줄일 수 있는 장점이 있다고 하였다. 그러나 마취 및 수술 시에는 환아가 시행받은 C1-C2 fixation으로 인한 경부 신전의 제한과, 다운증후군 환자의 구조적 특성으로 인한 기도 확보의 어려움으로 기도 확보를 위해 시도할 여러 가지 방법을 준비해야 한다는 의견 이 있었다. 성인의 경우에는 경부 신전 제한으로 직접 후두경 의 사용을 통한 기관 삽관(direct laryngoscopy intubation) 이 어려울 것으로 예상되는 경우에는 굴곡 기관지경(fiberoptic bronchoscopy)을 사용한 각성 하 삽관(awake intubation)을 우선 고려하는데, 이 환아의 경우 협조가 불가능 하다고 판단되어 본원 마취통증의학과에서는 비디오 후두경 을 이용한 기관 내 삽관술(video-assisted laryngoscopy, GlideScope [Verathon Inc., Bothell, WA, USA]), 성문 위 기 도기(supraglottic airway device, i-gel ${ }^{\circledR}$ [Intersurgical Ltd., Wokingham, UK]) 사용 및 굴곡기관지경을 이용한 기관 내 삽관 등의 방법을 준비했고, 이 방법들로 기도확보가 되지 않 으면 응급 기관절개술까지 시행할 수 있도록 대비했다. 수술 중 환아 활력 징후가 불안정할 경우 집중치료실에서 관리할 수 있도록 사전에 준비하고 상기 사항들에 대해 환자 보호자 에게 충분한 설명과 동의하에 전신마취하 편도절제술을 시행 하기로 결정하였다. 또한 술후 일어날수 있는 출혈에 대해서 도 전신마취하에 출혈 조절이 필요할 수 있다는 것을 환자 보 호자에게 충분한 설명과 동의를 얻었다.

마취통증의학과에 의해 전신마취를 먼저 시행하였다. 응 급기관절개술을 피하기 위해서는 신경근차단제(neuromuscular blocker)를 사용하기 전에 기도평가를 먼저 시행해야 한다. 환아를 진정(sedation)시킨 후 기도평가를 먼저 시행하 였다. 환아에 대한 수기 환기(manual ventilation)가 용이하였 고, 직접 후두경을 통해 기도를 확인하였을 때, 성대의 $30 \%$ 가량이 확인되어 기도확보가 용이할 것으로 판단되어 이후, 신경근차단제(rocuronium bromide, Esmeron [MSD, The Netherlands])을 투여하였다. 기도 삽관은 경부의 신전없이 중립자세로 비디오 후두경(GlideScope)을 이용한 기관 내 삽관술을 통해 문제없이 시행되었다. 환아의 경우 성문하 협 착(subglottic stenosis)이 의심되어 uncuffed tube로 일반적 tube size보다 2단계 작은 5.5Fr sized wire tube를 사용하였 다. 삽관 후 leakage test를 시행 $\left(25 \mathrm{~cm} \mathrm{H}_{2} \mathrm{O}\right)$ 하였고, leakage 되지 않은 것을 확인 후 tube를 고정하였다. 이후 편도절제술 은 최대한 경부의 신전 없는 상태로 진행하였으며, 환아의 편 도를 확인하기 위해서 약 15도의 Trendelenburg position을 취할 수 있게 하였다. 수술은 수술 후 빠른 회복과 통증의 감 소를 위해 전기소작기 대신 Coblator ${ }^{\circledR}$ (EVac 70; Arthrocare corporation, Sunnyvale, CA, USA)를 이용하여 시행 
하였다. 수술 중 양측 편도 grade IV, 아데노이드 grade II 소 견을 보였으며 수술은 일반적인 편도 및 아데노이드 절제술 에 준해 진행되었고, 진행 중 환아의 활력 징후도 안정하여 수술 종료 후 기관 발관까지 특별한 합병증은 발생하지 않았 다. 수술 후 1 일째 찬유동식으로 식사를 시작했으며, 수술 후 7일까지 수술 부위 출혈 등의 합병증 없고 식사량도 많이 회 복되는 경과를 보였다. 수술 14 일 이후에는 통증이 거의 없는 상태로 평소대로 식사할 수 있어서 일반 식이를 시작했으며 수술 부위도 잘 회복되었고 코골이 역시 호전되었다.

\section{고 찰}

수면 중 상기도의 폐쇄가 빈번하게 나타나는 것을 특징으 로 하는 폐쇄성 수면무호흡증은 소아 인구 중 대략 1\%-3\% 정도 나타나는 것으로 알려져 있다., ${ }^{1,6}$ 다운증후군 환아의 경 우 하악 저형성과 설비대를 가지고 있어서 수면 중 상기도 폐 쇄의 가능성이 높아지기 때문에 폐쇄성 수면무호흡증이 더

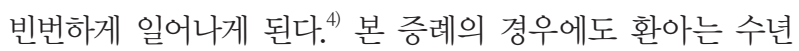
전부터 코골이와 수면무호흡증이 있었다. 수면무호흡은 심장 및 뇌혈관 질환의 이환율을 높이기 때문에 교정하는 것이 중 요하다. ${ }^{7)}$ 본 증례의 환아와 같이 다운증후군 환아에서 선천 성 심기형이 있는 경우 수면무호흡 교정은 더욱 중요하게 여 길 필요가 있다.

다운증후군 환자의 수술 시에는 여러 가지 주의해야 할 점 과 고려해야 할 점이 많기 때문에 마취의 시작부터 수술 및 회 복까지 다양한 상황들을 고려하여 대비해야 한다(Table 1). ${ }^{8}$ 전신마취를 위한 기도 삽관 시에는 환축추 불안정으로 인해
경부 신전에 유의해야 하며 ${ }^{9}$ 비만, 하악 저형성과 설비대로 인해 기도 확보에도 어려움을 겪을 수 있다. ${ }^{10)}$ 본 증례의 경우 환축추 불안정으로 8년 전 제1-2 경추 고정술을 시행한 과거 력이 있어 경부 신전으로 인한 환축추 탈골과 같은 합병증이 나타날 확률은 낮지만, 수술로 인해 경부 신전 자체가 잘 되 지 않는 상태였다. 본 증례에서는 경부의 신전 없이 중립 자 세로 비디오 후두경(GlideScope)을 이용한 기관내 삽관술을 통해 기도 확보를 하였다. ${ }^{11)}$ 또한 수술 중 활력 징후가 불안정 한 경우, 수술 후 즉시 발관하지 않고 집중치료실에서 관리 후 에 발관을 시도하는 것이 좋다. ${ }^{12)}$ Goldstein 등 ${ }^{13)}$ 은 다운증후 군 환자에서 수술 후 평균 1.4일, 집중치료실에서 관리 받은 경우가 전체의 $25 \%$ 정도로 다운증후군이 없는 환자에 비해 유의미하게 높았다고 보고하였다. 본 증례의 경우 수술 중 활력 징후가 안정적이었고, 특이사항 없이 수술이 잘 마무리 되어 수술 후 바로 발관하였으며 특이 합병증 없이 잘 마무리 되었다.

경부 신전은 마취뿐 아니라 편도 및 아데노이드의 수술 시 에도 시야 확보를 위해 중요한 부분이다. 하지만 본 증례의 경우 경부 신전의 제한이 있기 때문에 경부 신전을 최소한으 로 제한하고 수술을 진행하였다. 또한 전기소작기를 이용하지 않고, Coblator ${ }^{\circledR}$ 를 이용하여 수술을 시행하였는데, 이는 $\mathrm{Co}^{-}$ blator ${ }^{\circledR}$ 를 이용하여 수술을 시행하면 수술 시간의 단축과 수 술 후 통증 및 합병증이 감소한다는 보고를 바탕으로 결정했 다. ${ }^{14)}$ Coblator $^{\circledR}$ 사용으로 인한 수술 시간의 단축은 환아의 수술 후 즉시 발관의 가능성을 높이고, 수술 후 통증 및 출 혈의 감소와 회복 시간의 단축을 기대할 수 있다. 본 증례의 환아는 수술 후 1 주차에 코골이 및 수면무호흡증의 호전을

Table 1. Anesthetic management with Down syndrome

\begin{tabular}{|c|c|}
\hline \multicolumn{2}{|l|}{ Preop. } \\
\hline Preoperative management & - Consider use of anxiolytic premedication and aspiration precautions \\
\hline Type of anesthesia & $\begin{array}{l}\text { - Consider use of regional anesthesia if tolerated and no contraindications. Blocks can be } \\
\text { placed asleep or awake } \\
\text { - Induction of anesthesia can be inhalational, intravenous, or rapid sequence depending on } \\
\text { patient history }\end{array}$ \\
\hline \multirow[t]{2}{*}{ Airway management } & - Expect a difficult airway and have equipment available \\
\hline & - Use cervical spine precautions and a smaller endo-tracheal tube \\
\hline \multicolumn{2}{|l|}{ Intraop. } \\
\hline \multirow[t]{3}{*}{ Intraoperative management } & - Carful positioning given ligamentous laxity \\
\hline & - If indicated, give antibiotic prophylaxis for spontaneous bacterial endocarditis \\
\hline & $\begin{array}{l}\text { - Careful fluid management and hemodynamic monitoring, particularly if congenital heart } \\
\text { disease is present }\end{array}$ \\
\hline \multicolumn{2}{|l|}{ Postop. } \\
\hline \multirow[t]{2}{*}{ Postoperative management } & - Use multimodal pain control and alternative pain scales \\
\hline & $\begin{array}{l}\text { - Consider if intensive care monitoring is needed, given congenital heart disease or other } \\
\text { pathology }\end{array}$ \\
\hline
\end{tabular}


보였고, 식사량도 이전처럼 늘어났으며 수술 후 2주차에는 수술 전과 같은 활동성을 보여주며 빠르게 회복한 모습을 보 였다. 본 환아의 경우 수술 후 코골이 및 수면무호흡이 호전 되는 양상을 보였지만, 다운증후군 환자에서 편도 및 아데노 이드 수술 후에도 코골이 및 수면무호흡 증상이 지속된다면 수면다원검사 및 후두내시경과 영상검사 등을 시행하여 원인 을 재평가하고, 그에 따라 양압기, 체중조절 같은 비수술적인 치료부터 설편도 절제 및 혀 축소술 등의 추가적인 수술적 치 료도 고려해볼 수 있을 것이다. ${ }^{15)}$ 저자들은 환축추아탈구와 심방중격결손이 합병증으로 있는 다운증후군 환아에서 편도 및 아데노이드 절제술을 합병증 없이 안전하게 시행하여 폐 쇄성 수면무호흡증을 성공적으로 치료하였기에 이를 보고하 는 바이다. 본 증례와 같이 여러 가지 이유로 경부 신전의 제 약이 있는 환자를 수술할 때는 치료 전에 면밀하게 계획을 세 우고 여러가지 돌발 상황에 대비해 충분한 논의와 다양한 준 비가 필요할 것이다.

\section{Acknowledgments}

This study was supported by the Basic Science Research Program through the National Research Foundation of Korea (NRF2018M3A9F1023697), and was also supported by a grant of the Korea Health Technology R\&D Project through the Korea Health Industry Development Institute (KHIDI), funded by the Ministry of Health \& Welfare, Republic of Korea (HU21C0098)

\section{Author Contribution}

Conceptualization: Young Hyo Kim. Data curation: Chang Bin Yun, Ki Jong Hyun. Formal analysis: Ki Jong Hyun. Investigation: Chang Bin Yun. Methodology: Hyunzu Kim, Young Hyo Kim. Supervision: Hyunzu Kim, Young Hyo Kim. Visualization: Ki Jong Hyun. Writing — original draft: Chang Bin Yun. Writing — review \& editing: Hyunzu Kim, Young Hyo Kim.

\section{ORCIDs}

Young Hyo Kim

https://orcid.org/0000-0002-3623-1770

Chang Bin Yun

\section{REFERENCES}

1) Marcus CL. Sleep-disordered breathing in children. Curr Opin Pediatr 2000;12(3):208-12.

2) Marcus CL, Brooks LJ, Draper KA, Gozal D, Halbower AC, Jones $\mathrm{J}$, et al. Diagnosis and management of childhood obstructive sleep apnea syndrome. Pediatrics 2012;130(3):576-84.

3) Goldstein NA, Fatima M, Campbell TF, Rosenfeld RM. Child behavior and quality of life before and after tonsillectomy and adenoidectomy. Arch Otolaryngol Head Neck Surg 2002;128(7): $770-5$.

4) Shott SR, Amin R, Chini B, Heubi C, Hotze S, Akers R. Obstructive sleep apnea: Should all children with Down syndrome be tested? Arch Otolaryngol Head Neck Surg 2006;132(4):432-6.

5) Meitzner MC, Skurnowicz JA. Anesthetic considerations for patients with Down syndrome. AANA J 2005;73(2):103-7.

6) Li Z, Celestin J, Lockey RF. Pediatric sleep apnea syndrome: An update. J Allergy Clin Immunol Pract 2016;4(5):852-61.

7) Muzumdar HV, Sin S, Nikova M, Gates G, Kim D, Arens R. Changes in heart rate variability after adenotonsillectomy in children with obstructive sleep apnea. Chest 2011;139(5):1050-9.

8) Malinzak EB. Perioperative care of adults with Down syndrome: A narrative review. Can J Anaesth 2021;68(10):1549-61.

9) Pueschel SM, Scola FH. Atlantoaxial instability in individuals with Down syndrome: Epidemiologic, radiographic, and clinical studies. Pediatrics 1987;80(4):555-60.

10) Nakazawa $K$, Ikeda $D$, Ishikawa $S$, Makita $K$. A case of difficult airway due to lingual tonsillar hypertrophy in a patient with Down's syndrome. Anesth Analg 2003;97(3):704-5.

11) Bhattarai B, Kulkarni AH, Rao ST, Mairpadi A. Anesthetic consideration in downs syndrome--a review. Nepal Med Coll J 2008;10(3):199-203.

12) Santamaria LB, Di Paola C, Mafrica F, Fodale V. Preanesthetic evaluation and assessment of children with Down's syndrome. ScientificWorldJournal 2007;7:242-51.

13) Goldstein NA, Armfield DR, Kingsley LA, Borland LM, Allen GC, Post JC. Postoperative complications after tonsillectomy and adenoidectomy in children with Down syndrome. Arch Otolaryngol Head Neck Surg 1998;124(2):171-6.

14) Mitic S, Tvinnereim M, Lie E, Saltyte BJ. A pilot randomized controlled trial of coblation tonsillectomy versus dissection tonsillectomy with bipolar diathermy haemostasis. Clin Otolaryngol 2007;32(4):261-7.

15) Strome M. Obstructive sleep apnea in Down syndrome children: A surgical approach. Laryngoscope 1986;96(12):1340-2. 